\title{
Transformation of Local Wisdom Value as An Effort to Establish Nation Characters in Simeulue District
}

\author{
Hasbi Ali $^{1}$, Ruslan ${ }^{2}$ and Irma Anggraini ${ }^{3}$ \\ ${ }^{1}$ Civics Department Faculty of Education Unsyiah \\ ${ }^{2}$ Civics Department Faculty of Education and Student Ph.D. Social Education Unsyiah \\ ${ }^{3}$ Department of Economic Education Unsyiah \\ \{1asbysagita@yahoo.co.id, ${ }^{2}$ ruslan@unsyiah.ac.id\}
}

\begin{abstract}
The framework of cultural transformation is structure and culture. This cultural transformation is a form of preservation of local wisdom in a particular society with the main goal is the culture is not extinct eroded by the current global culture. The problems in this study are (1) the role of local wisdom values in the formation of students' character, (2) Transforming the values of local wisdom as an effort to shape the nation's character in the learning process, and (3) Constraints in the transformation of local wisdom values as an effort to shape the nation's character in the learning process. This study uses a qualitative approach, while the type of research is descriptive. After the data has been collected through the interviews, then the data is analyzed qualitatively. Research results (1) Local wisdom culture is very instrumental in the formation of students' character, (2) The efforts to transform the values of local genius are carried out through the subjects of Cultural Arts and Crafts and according to the teacher, the character building of students this is the responsibility of all teachers. In addition, the formation of students' character through local wisdom values learning is carried out through extra-curricular activities under the guidance of Deputy Principal of Student Affairs, and (3) Constraints experienced by teachers in transforming the values of local wisdom is the absence of regulation from the local government regarding local content learning because in the Aceh education Qanun it is emphasized that learning local content in each type and level of education needs to be regulated by the governor regulation which until now has not yet come out. Conclusion: (1) That the values of local wisdom is very instrumental in the formation of students' character because it contains many useful advice in daily life, (2) The teacher's efforts to transform the values of local wisdom in the learning process as an effort to shape the character of students is through the subjects of Cultural Arts and Crafts and according to the teacher actually the character building of these students is the responsibility of all teachers. In addition, the formation of students' character through learning local wisdom values is done through extra-curricular activities, and (3) Constraints experienced by teachers in the absence of regulation from the local government regarding local content learning.
\end{abstract}

Keywords: Local Wisdom Value, Nation Character 


\section{Introduction}

National education works to develop the ability and to shape of dignified national character and civilization in order to educate people, aims to develop the potential of students to become the believers and fear of God Almighty, noble, healthy, knowledgeable, capable, creative, independent and become a democratic and responsible citizen as stipulated by the Article 3 of Law Number 20 of 2003 concerning the National Education System.

Therefore, educators are expected to transform the values of local wisdom in each learning process across disciplines. Integrating the values of the nation's character in the learning process as an effort to reduce global influences that can damage students' character along with the current of modernization.

Culture cannot be separated from all patterns of community and cultural activity and also has a very vital role in the process of internalizing the values of life to the younger generation. However, along with the times, the existence of culture and cultural values possessed by the Simeulue community until now has not been optimal in the effort to transform the generation afterward.

Ranjabar [1] refers to the idea of Machfiroh [2] (the original source) said that judging from the plural nature of Indonesian society, it must be accepted that there are three cultural groups, each of which has its own style, namely: (1) Culture of ethnic groups, (2) Culture local general (regional culture), and (3) national culture. In this case, transformation is a shift of something in another direction or new without changing the structure contained therein, even though in its new form it has changed. The framework of cultural transformation is structure and culture. This cultural transformation is a form of preservation of local wisdom in a particular society with the main goal that culture is not extinct eroded by the current global culture.

Based on the problems stated above, this study examines in more depth about: Transforming local wisdom value as a nation character-building effort in the learning process. This is needed not only to fortify students from the negative influence of globalization but as an effort to preserve the culture of local wisdom itself.

\section{Literature Review}

\subsection{Local Wisdom Transformation}

Referring to the structure and level, local wisdom is at the level of culture. This is based on a socio-cultural scheme in Indonesia, which consists of a pluralistic society in social, cultural (multicultural) and economic structures. Ranjabar [1] refers to the idea of Machfiroh [2] (the original source) (the original source) said that judging from the plural nature of Indonesian society, it must be accepted that there are three cultural groups, each of which has its own style, namely: (1) Culture of ethnic groups, (2) Culture local general (regional culture), and (3) national culture.

This is in accordance with the opinion of Koentjaraningrat [3] that local culture related to the term ethnicity itself is: "A human group that is bound by awareness and identity of cultural unity, in this case, the element of language is its trademark". Regarding local culture as local wisdom, Garna [4] said that local wisdom is part of a scheme of cultural levels. Local culture is complementary to regional culture and regional culture are essential parts of the formation of national culture.

In a broad sense, Garna [4] said that regional culture is not only revealed from the form and statement of a sense of beauty through mere art, but includes all forms and ways of behaving, 
acting, and patterns of thought that are far in behind what looks like. Therefore, certain administrative areas can be a cultural area of a region or cultural region that includes several administrations, or in an administrative area will consist of a part of regional culture.

Reflecting on the 2004 earthquake and Tsunami that hit the province of Aceh, the Simeulue folklore is clear evidence of the importance of cultural transformation in the younger generation. The collective memory of the Simeulue community about the great Tsunami in 1907 known by the local community as Smong has been proven to save the Simeulue people from the Tsunami disaster.

The Aceh Tsunami in 2004 killed 170,000 people (Reuters, 10/28/08). Starting from an earthquake measuring 9.3 on the Richter scale that triggered a tidal wave with a speed of 2.5 $\mathrm{km} / \mathrm{sec}$ which hit 13 countries along the Indian Ocean coast. Looking at other perspectives, the Tsunami that occurred in Aceh proved that the local wisdom of the Simeulue community about Smong as local wisdom managed to survive and be effective in dealing with natural disasters. Smong is an understanding of the past culture that has been collectively embedded in Simeulue society. Smong in its concrete form is a story (nanga-nanga, sikambang dance, or nandong traditional music) or traditional art in the form of singing. There are also pieces from the Simeulue folklore about Smong, a poem that is told as a bedtime story by the people of Simeulue, a bedtime tale.

The Smong term was known by the Simeulue community after the Tsunami tragedy on Friday, January 4, 1907. The earthquake followed by a massive tsunami that occurred in the Simeulue was still in the era of the Dutch East Indies. This Tsunami disaster was recorded in the Dutch book S-GRAVENHAGE, MARTINUSNIJHOF in 1916 which was translated into Indonesian. At that time the Simeulue community did not know about this Tsunami, the ocean that suddenly receded after the earthquake became an attraction for coastal communities because many fish were found stranded. The majority of the coastal population ran towards the beach and fought for the stranded fish, but surprisingly suddenly came a massive wave that rushed from the direction of the high seas, so most of the people died. Some survivors were eyewitnesses of the Smong incident and told it to the future generations to be careful of similar incidents [5].

The collective memory of the Simeuluenese about this Smong linked to the devastating Tsunami that hit Aceh Province in 2004 will be another condition. At the time of the 2004 Aceh earthquake and tsunami in the entire Simeulue District, more than 1,700 houses were destroyed by the tsunami, but the death toll was 6 . It is estimated that in Simeulue the average population of one house is approximately 5 people, then the total number of people whose houses were hit by the Tsunami is more than 8,500 people or about $10 \%$ of the total population of Simeulue regency. This means that at that time there was a large-scale evacuation process in less than 10 minutes simultaneously in the entire coastal area of Simeulue island which has a coastline of $400 \mathrm{KM}$. Given that the telecommunications infrastructure in Simeulue regency was very limited, the mass mobilization event was an extraordinary event.

\subsection{The Role of Teachers Transforming Local Wisdom Values as an Effort to Form Nation Character in the Learning Process}

The success of a learning process is determined by the role and function of the teacher, as the spearhead of the learning process. This is as mandated by the Article 39 paragraph (2) of Law Number 20 of 2003 concerning the National Education System that: "Educators are the professionals who are tasked with planning and implementing the learning process, assessing 
learning outcomes, conducting guidance and training, as well as conducting research and dedication to the community, especially for educators in universities".

Furthermore, Article 40 paragraph (2) of Law Number 20 of 2003 concerning the National Education System explains more about the role of teachers as educators, namely: "Educators and education personnel are obliged to (a) Create an educational atmosphere that is meaningful, fun, creative, dynamic, and dialogical, (b) Have a professional commitment to improving the quality of education, and (c) Give an example and maintain the good name of the institution, profession, and position in accordance with the trust given to him or her". Based on the article, it can be concluded that a teacher needs to increase his or her creativity in order to generate more enjoyable and meaningful learning so that students are motivated in learning.

Tirtarahardja \& Sula [6] said that a teacher had the role and function stated below:

1. Teacher as an educator. A teacher is an educator becoming a figure, a leader for the students and people around.

2. Teacher as an instructor. A teacher helps the students to learn something unknown, to form the competency, and to understand the standard material learned.

3. Teacher as an adviser. A teacher is responsible for the great learning process based on knowledge and experience.

4. Teacher as a trainer. Teachers in their roles and functions as the trainers familiarize a number of skills to the students in the learning process.

In the activities of the teaching and learning process includes many things. Therefore, Sudjana [7] said: "The teacher's duty as a profession includes educating, teaching and training. Educating means continuing and developing the values of life and life itself. Teaching means continuing and developing science and technology. While training means developing skills among students. One that must be trained and formed by the teacher is about the character of students.

Munir [8] defined the character as: "A good pattern of thoughts, attitudes, and actions that are inherent in a person with a very strong and difficult to eliminate". In this case, Budimansyah[9] further explained that: "The essence of the character is goodness in the sense of good thinking, good filling, and good behaving." Added Megawangi [10] that: "Noble character is not automatically possessed by every human once was born, but requires a long process through care and education (the process of engraving). From some of these opinions showed that the role of the teacher as an educator is vital in shaping the character of students in accordance with the character of the nation.

The formation of the students' character is a form of transformation of the values of goodness by the teacher so that they have a Pancasila personality. Gaffar [11] referring to Kesuma, Triatna, $\&$ Permana [12] idea (the original source) defined character as: "A process of transforming the values of life to be developed in one's personality, so that it becomes one of the forms of behavior". Thus, it is expected that the creation of stable personality learners as stated by Prayitno \& Manullang [13] that: Character is a more stable personal trait in the individual who is the basis for the appearance of behavior in high standards and norms.

Sumantri [14] defined character as: "Character and personality of a person are formed from the results of internalization of various virtues". From this definition, Kesuma [12] provided the aim of character building for students is:

1. Strengthening and developing the values of life that are considered important and necessary, so that they become the typical personality as the values developed.

2. Advising students' behavior that is not in line with the values developed by the school.

3. Building a harmonious connection with family and society in implementing the responsibility of character education together. 
The formation of the students' character must be continuously carried out by the teacher as the front guard who forms the nation's character so that students can ultimately behave in accordance with the noble values of the nation. There were no more brawls between students, alcohol, free sex, and other immoral acts carried out by the young generation in an effort to welcome the 100-year-old Golden Generation of independent Indonesia in 2045.

\subsection{Objectives and Benefits of Research}

\subsubsection{Research Objectives}

1. To determine the role of local wisdom values in the formation of students' character.

2. To transform the values of local wisdom as an effort to shape the nation character in the learning process.

3. To find out the constraints of transforming local wisdom values as an effort to shape the nation character in the learning process.

\subsubsection{Research Benefits}

1. The results of this study are expected to be useful in enriching the literature of scientific reading in an effort to support the development of social and cultural knowledge.

2. The results of this study are expected to support national development related to strengthening the culture of local wisdom.

3. For teachers, the results of this study are expected to be a theoretical contribution to transforming the culture of local wisdom in the learning process as an effort to characterize students.

\section{Method}

\subsection{Research Methods}

This study uses a qualitative approach, while the type of research is descriptive. The choice of approach and type of research is in accordance with the problems to be studied, namely the Transformation of Local Wisdom Value as an effort to form nation character in the learning process in Simeulue district.

Semeulue regency is one of the districts located in those frontier, outermost and least developed regions often referred to as $3 \mathrm{~T}$ ( terdepan, terluar, tertinggal ) regions, \pm 300 miles from the west coast of Aceh province.

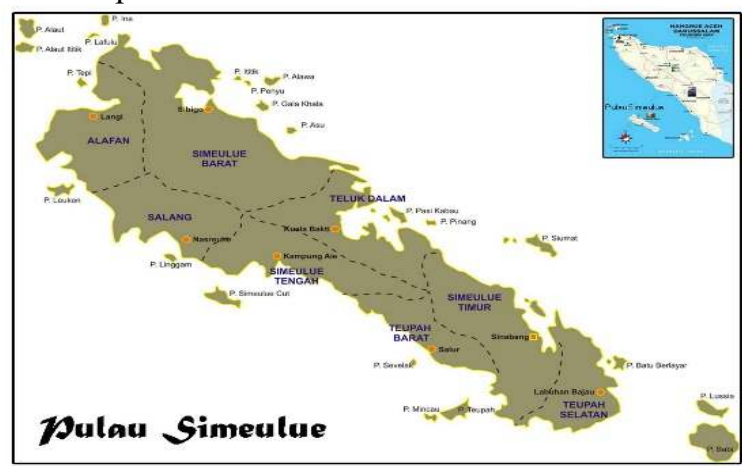

Figure 1: Maps that show the research location 


\subsection{Research Data Analysis Techniques}

After the data has been collected through the interviews, then the data are analyzed qualitatively with the following steps: (1) Data reduction, namely simplification and selection of data in accordance with the problems to be studied, (2) Presentation of data, namely describing data that has been collected narratively, and (3) Drawing the conclusions/ verification which are the final stages of the analysis of research data.

\subsection{Research procedure}

Data collection in this research has been conducted through the structured interviews based on the interview guidelines that had been prepared previously by the research team and Peer Group. Questions raised in interviews related to the transformation of local wisdom values as local character formation efforts in the learning process in Simeulue regency. The information that would be collected in this study includes. The strategy of the teacher transforming the values of local wisdom (local genius) as an effort to shape the nation character in the learning process. The information that will be collected includes:

1. Information requested from the Department of Education and Culture

a. Local content material according to the regional potential.

b. Local culture transformation program to the schools.

c. The availability of the local culture educator in the school.

d. The coordination with relevant agencies, such as the Aceh Traditional Council of Simeulue district.

2. The information required by the teachers

a. Teacher's knowledge of the local wisdom culture in Simeulue district.

b. Efforts to transform the culture of local wisdom in the learning process.

c. Cultural transformation strategies of local wisdom in the learning process.

d. Constraints faced in the transformation of local wisdom culture in the learning process.

e. Communication with relevant agencies in connection with the transformation of local wisdom in the learning process.

3. Information requested from students

a. Knowledge of students about the culture of local wisdom.

b. Sources of knowledge of students about the culture of local wisdom.

c. Students' perception of the culture of local wisdom.

d. Students' perception of cultural transformation of local wisdom.

e. Students' perceptions of the cultural degradation of local wisdom.

The steps of the research activities can be seen in Figure 2. Research Flow Chart 
Transformation Analysis of Local Wisdom Values:

1. The teacher's strategy in transforming the values of local wisdom in the learning process.

2. The teacher's constraints in transforming the values of local wisdom in the learning process.

3. The preparation of the teacher learning design in transforming the values of local wisdom in the learning process.

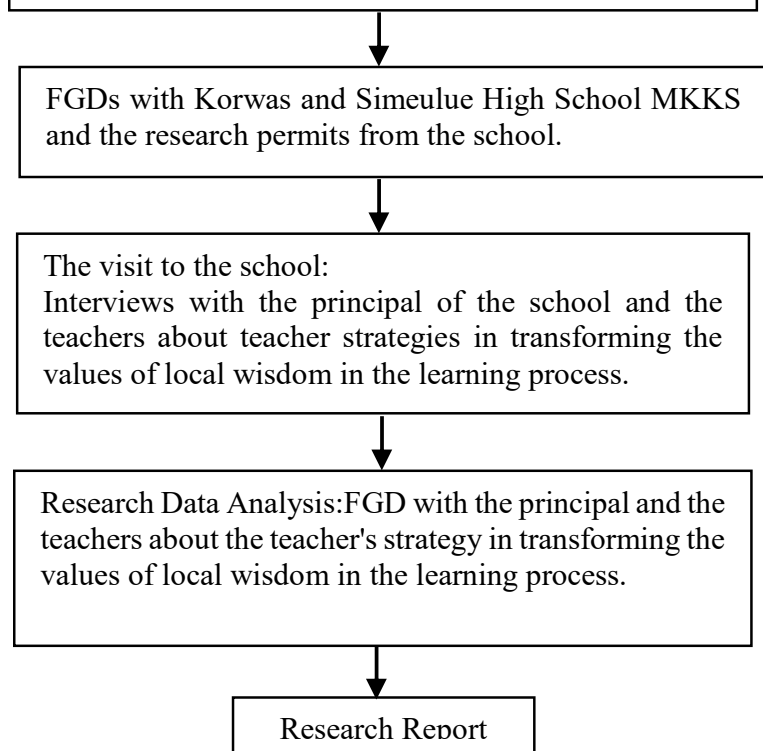

Figure 2: Research Flow Chart.

\section{Result and Discussion}

\subsection{Research Result}

This research was conducted in 3 (three) different high schools based on the characteristics of education unit including the advanced senior high schools (SMAN 1 East Simeulue), underdeveloped (SMAN 1 Central Simeulue), and less advanced (SMAN 1 West Teupah). The results of interviews with the teachers at the schools showed the following results. 
Knowledge of the local wisdom culture found that not all high school teachers in Simeulue district had an adequate knowledge. Whereas, all this time the teachers have only taught the general culture both local, regional and national culture. Local culture taught by the teacher to students such as Mangasila dance (salt processing) and Mansinasa skills (pandan mat weaving), regional cultures such as Bungong Jeong dance, and national cultures such as dances from various regions in Indonesia.

The limitation of teachers' knowledge about the culture of local wisdom is due to the lack of socialization carried out by relevant institutions, for example the Aceh Traditional Council of Simeulue district. In SMAN 1 West Teupah, a cultural seminar has indeed been conducted, but the information received by teachers is still very limited. This was proved when the researchers mentioned some of the local wisdom cultures obtained from the results of previous studies, the teachers said they had just heard it without deep understanding. (Interview on 11-16 May 2018).

Therefore, from this research, it can be concluded that generally high school teachers in Simeulue district still have very limited knowledge about the local wisdom culture due to the lack socialization from the relevant agencies. This condition causes the teachers to be difficult in transforming the values of local wisdom to students in the learning process as an effort to characterize the nation character.

The effort of cultural transformation of local wisdom in the learning process found that according to the teacher who became the informant in this research, the nation character building became the responsibility of all teachers and was not charged to the certain teachers who were done through habituation. Associated with the transformation of the values of local wisdom that it is only done by teachers who gave more attention to the subjects of Cultural Arts and Crafts. However, the transformation effort is very much tied to the existing curriculum.

In this case, the transformation of local wisdom values only becomes the smallest part of the learning process. Teachers are not given an authority to improvise in the learning process and they are only pursuing a predetermined curriculum achievement target. (Interview on 11-16 May 2018).

Thus, it can be concluded that the effort to transform the values of local wisdom in the learning process as an effort to characterize students is only done a little by the teacher because according to them the formation of students' character is the responsibility of all teachers through learning. Associated with the culture of local wisdom that it is only the full responsibility of the Arts and Culture teacher.

The strategy of cultural values transforming of local wisdom is carried out in the learning process of Cultural Arts and Crafts through various art performances, both in the form of songs and dances and skills related to the life skills of students. In this case, the Cultural Arts and Craftsman teacher forms the small groups of students to practice certain arts.

Associated with the culture of local wisdom, the teachers of Arts and Culture could not cope with all the knowledge about it, only a small part is taught. The teachers assume that learning about the culture of local wisdom is only as a local content which is further regulated in the school curriculum. However, local content that has been taught is not related to the culture of local wisdom such as local language, Arab Malay, and German because of the availability of the human resource.

The teachers experience the constraints of transforming local wisdom in the learning process, especially through local content because it is related to the lack of regulation from the local government. According to the teacher, local content subject learning was applied to the Kurikulum Tingkat Satuan Pendidikan (school-based curriculum) in the previous period, but in the 2013 Curriculum, the teacher was no longer justified in teaching the local content subject because there must be a decree from the governor initially. 
In fact, according to the teacher local content learning is very helpful for them in fulfilling mandatory hours for teachers who have been certified because they have their own learning hours. However, with the enactment of the rule that local content learning must be based on the governor's decision, the learning process is temporarily stopped indefinitely.

The urgency of local content learning is realized by the teacher as an effort to characterize students who are rooted in the local wisdom of local communities but constrained by the absence of regulations that regulate it. Meanwhile, local content learning material which is inserted in the subjects of Culture and Workshops is only limited to the crafts and local dances of the Simeulue community.

The regulation of the implementation of local content learning as stipulated in article 44 of the Aceh Qanun Number 11 of 2014 concerning the Implementation of Education, paragraph (2) point b and paragraph (3), stated that:

- Paragraph (2) points b: Local content includes:

1. Local language

2. Aceh history

3. Tradition, culture and local wisdom

4. Skills education

- $\quad$ Paragraph (3), further provisions regarding school curriculum in all types and levels of education are regulated by the Governor's Regulation.

The efforts to transform the values of local wisdom in this learning process have often been communicated with various related institutions, such as the Simeulue Education and Culture Department. However, the response from the relevant agencies is constrained by the lack of regulation that regulates it. The teachers expect the Governor Regulation will be issued to regulate the process of local content learning so that teachers have a strong legal basis to implement it.

Based on the results of the researchers' confirmation to the Aceh Education and Culture Department related to local content learning in each type and level of education, it was found that it has not been implemented because the Governor Regulation is not yet to be issued. The Government of Aceh has established a Local Content Curriculum Development Team in Aceh province under the coordination of the Aceh Regional Education Council. The development team is currently conducting a local content curriculum study, then later it will be evaluated by another team before the Governor Regulation will be released.

This shows that the local learning subject processes have not been carried out at all levels and types of education in Aceh. It is caused by the regulation regulating it has not been realized, as mandated that the learning is regulated through the local governor regulation. Therefore, before the issuance of the regulation in Aceh province, there was no learning process about the local content subject.

\section{Conclusion and Suggestion}

\subsection{Conclusion}

1. The teacher realizes that the values of local wisdom are very instrumental in the formation of students' character because it contains much useful advice in daily life.

2. Teachers have been trying to transform the values of local wisdom in the learning process as an effort to shape the character of students through the subjects of Cultural Arts and Crafts and according to the teacher the character building of students is actually the responsibility of all teachers. In addition, the formation of students' character through the 
learning of the values of local wisdom is carried out through extracurricular activities under the guidance of the Deputy Principal of Student Affairs.

3. The teacher transforms the values of local wisdom in the learning process as an effort to characterize students currently experiencing problems, namely the lack of regulation from the local government about local content learning because in the Aceh education Qanun emphasized that local content learning in each type and level education needs to be regulated by the Governor Regulation which until now has not yet released.

\subsection{Suggestion}

1. It is expected that the local government and other relevant agencies to issue the regulations on learning local content in each type and level of education immediately so that the teachers have guidance on learning as an effort to characterize students.

2. It is expected that the teacher is able to teach the values of local wisdom through various activities both curricular and extracurricular while the issuance of regulations on the learning of local content from the local government has not been released.

\section{REFERENCES}

[1] J. Ranjabar, Sistem sosial budaya Indonesia. Bogor: Ghalia Indonesia, 2006.

[2] R. Machfiroh, "Revitalisasi karakter bangsa melalui pendidikan kewarganegaraan dengan pengembangan budaya lokal (Studi kasus budaya Macapat di masyarakat kota Surakarta Jawa Tengah)," Universitas Pendidikan Indonesia, 2011.

[3] Koentjaraningrat, Sejarah teori antropologi I. Jakarta: UI Press, 2009.

[4] Y. K. Garna, Budaya Sunda: Melintasi waktu menantang masa depan. Bandung: Lembaga Penelitian Unpad dan Judistira Garna Foundation, 2008.

[5] Armidin, "Tsunami Mentawai dan kearifan smong Simeulue," Kompasiana, 2015. .

[6] U. Tirtarahardja and L. Sula, Pengantar pendidikan. Jakarta: Rineka Cipta, 2000.

[7] N. Sudjana, Dasar-dasar proses belajar mengajar. Bandung: Sinar Baru Algensido Offset, 2004.

[8] A. Munir, Pendidikan karakter (Membangun karakter anak sejak dari rumah). Yogyakarta: Pedagogis, 2010.

[9] D. Budimansyah, Penguatan pendidikan kewarganegaraan untuk membangun karakter bangsa. Bandung: Widya Aksara Press, 2010.

[10] R. Megawangi, Pendidikan karakter (Solusi yang tepat untuk membangun bangsa). Jakarta: BP-MIGAS, 2004.

[11] F. Gaffar, "Pendidikan karakter berbasis Islam," in Workshop pendidikan karakter berbasis agama, 2010.

[12] D. Kesuma, C. Triatna, and J. Permana, Pendidikan karakter: Kajian teori dan praktik di sekolah. Bandung: PT Remaja Rosdakarya, 2011.

[13] Prayitno and B. Manullang, Pendidikan karakter dalam pembangunan bangsa. Medan: Pascasarjana Unimed, 2010.

[14] N. Sumantri, Pendidikan budaya dan karakter suatu keniscayaan bagi kesatuan dan persatuan bangsa. Dalam pendidikan karakter: Nilai inti bagi upaya pembinaan kepribadian bangsa. Bandung: Laboratorium PPKn UPI, 2011.

[15] Simeulueblogger, "Sekilas tentang Simeulue," Simeulueblogger, 2016. . 